\title{
Characteristics of the size distribution of recent and historical landslides in a populated hilly region
}

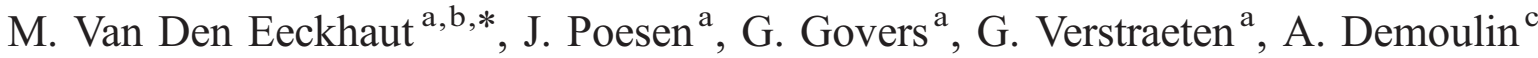 \\ ${ }^{a}$ Physical and Regional Geography Research Group, K.U. Leuven, Celestijnenlaan 200E, B-3001 Heverlee, Belgium \\ ${ }^{\mathrm{b}}$ Post-doctoral fellowship, Fund for Scientific Research - Flanders, Belgium \\ ${ }^{c}$ Department of Physical Geography and Quaternary, Liège University, Belgium
}

Received 14 September 2006; received in revised form 17 January 2007; accepted 21 January 2007

Available online 11 February 2007

Editor: G.D. Price

\begin{abstract}
Despite the availability of studies on the frequency density of landslide areas in mountainous regions, frequency-area distributions of historical landslide inventories in populated hilly regions are absent. This study revealed that the frequency-area distribution derived from a detailed landslide inventory of the Flemish Ardennes (Belgium) is significantly different from distributions usually obtained in mountainous areas where landslides are triggered by large-scale natural causal factors such as rainfall, earthquakes or rapid snowmelt. Instead, the landslide inventory consists of the superposition of two populations, i.e. (i) $\mathrm{small}\left(<1-2 \cdot 10^{-2} \mathrm{~km}{ }^{2}\right)$, shallow complex earth slides that are at most $30 \mathrm{yr}$ old, and (ii) large $\left(>1-2 \cdot 10^{-2} \mathrm{~km}^{2}\right)$, deep-seated landslides that are older than $100 \mathrm{yr}$. Both subpopulations are best represented by a negative power-law relation with exponents of -0.58 and -2.31 respectively. This study focused on the negative power-law relation obtained for recent, small landslides, and contributes to the understanding of frequency distributions of landslide areas by presenting a conceptual model explaining this negative power-law relation for small landslides in populated hilly regions. According to the model hilly regions can be relatively stable under the present-day environmental conditions, and landslides are mainly triggered by human activities that have only a local impact on slope stability. Therefore, landslides caused by anthropogenic triggers are limited in size, and the number of landslides decreases with landslide area.

The frequency density of landslide areas for old landslides is similar to those obtained for historical inventories compiled in mountainous areas, as apart from the negative power-law relation with exponent -2.31 for large landslides, a positive power-law relation followed by a rollover is observed for smaller landslides. However, when analysing the old landslides together with the more recent ones, the present-day higher temporal frequency of small landslides compared to large landslides, obscures the positive power-law relation and rollover.
\end{abstract}

(C) 2007 Elsevier B.V. All rights reserved.

Keywords: landslide area; frequency-size distribution; historical landslide inventory; anthropogenic triggering factors

* Corresponding author. Contact address: Physical and Regional Geography Research Group, K.U.Leuven, Celestijnenlaan 200E, B-3001 Heverlee, Belgium. Tel.: +32 163264 17; fax: +32 16323980 .

E-mail address: Miet.vandeneeckhaut@geo.kuleuven.be (M. Van Den Eeckhaut).

\section{Introduction}

In contrast to many mountainous regions, landslides (LS) are not always the most important natural hazard in hilly regions. There are, however, several examples of hilly regions where LS cause considerable damage to 


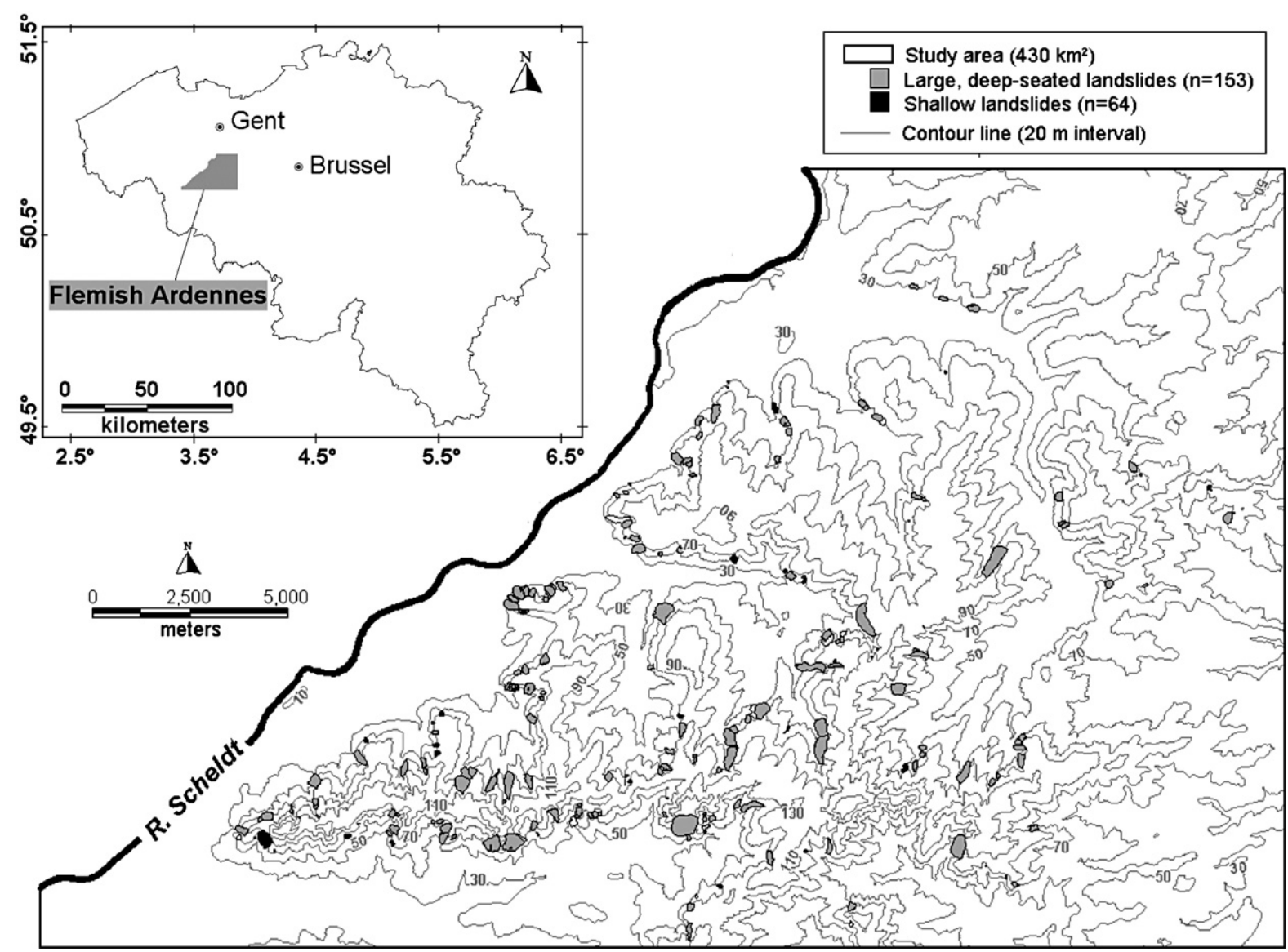

Fig. 1. Location of the landslides in the $430 \mathrm{~km}^{2}$ study area within the Flemish Ardennes (Belgium).

buildings and other infrastructure. One such region is the Flemish Ardennes (Belgium, Fig. 1). Recent LS studies in a $430 \mathrm{~km}^{2}$ study area revealed more than $200 \mathrm{LS}$, both dormant and active, with morphological characteristics that are still clearly visible in the field [1-3]. Statistical modelling (i.e. rare events logistic regression) showed that the location of LS in the study area is related to the presence of relatively steep slopes (hillslope gradient of depletion area $>0.20 \mathrm{~m} \mathrm{~m}^{-1}$ ) and lithologies rich in smectite clays [4]. Initiation or reactivation of LS generally occurs after periods with a monthly rainfall exceeding $100 \mathrm{~mm}$ and a 12-month antecedent rainfall exceeding $1000 \mathrm{~mm}$ [5], and is often related to inappropriate human activities on marginally stable hillslope sections [6].

For mountainous regions the geomorphological impact of LS is already widely discussed, e.g. through the analysis of frequency distributions of LS areas [7-25]. For large and medium-sized LS, LS frequency distributions are generally negative power-law (scale-invariant) functions of LS area (Table 1), even though results have been presented (i) as cumulative and non-cumulative frequency distributions, (ii) for LS scar areas, total LS areas, or LS volumes, (iii) for relative complete inventories of LS caused by one triggering event or for historical LS inventories, which are the sum of many single events and which are assumed to be incomplete as morphological characteristics of old shallow LS can be obliterated by erosion and human activities, and (iv) for inventories of LS triggered by rainfall, earthquakes, or rapid snowmelt. Therefore these power-law distributions of LS observed under various conditions have been associated with the concept of self-organized criticality (SOC; [26-30]). According to its definition, selforganized critical behaviour is characterized by steady inputs, and outputs that are a series of 'events' satisfying power-law frequency-size statistics [9]. In geomorphological studies, the sand pile model was a first, simple metaphor of a SOC process [26,27]. In this model sand particles are slowly added one by one to a pile. The grains are basically independent and their behaviour is described by gravity and friction. When a critical slope is reached, the addition of a single grain can generate an avalanche 
Table 1

Overview of studies that have reported frequency distributions of landslide (LS) areas in mountainous regions

\begin{tabular}{|c|c|c|c|c|c|c|c|c|}
\hline \multirow[t]{3}{*}{ Reference $^{\text {a }}$} & \multirow[t]{3}{*}{ Location } & \multirow{3}{*}{$\begin{array}{l}\text { Number } \\
\text { of LS }\end{array}$} & \multirow{3}{*}{$\begin{array}{l}\text { Size of } \\
\text { study area } \\
\left(\mathrm{km}^{2}\right)\end{array}$} & \multirow{3}{*}{$\begin{array}{l}\text { Type of } \\
\text { inventory }\end{array}$} & \multicolumn{4}{|l|}{ Relation } \\
\hline & & & & & & \multirow{2}{*}{$\begin{array}{l}\text { Location } \\
\text { rollover } \\
\left(t ; \mathrm{km}^{2}\right)\end{array}$} & \multicolumn{2}{|c|}{$\begin{array}{l}\text { Negative power-law for medium and } \\
\text { large LS }\end{array}$} \\
\hline & & & & & & & $\begin{array}{l}\text { Starting at } A_{\mathrm{L}} \\
\left(\mathrm{km}^{2}\right)\end{array}$ & $\begin{array}{l}\text { Exponent } \\
(\beta)\end{array}$ \\
\hline Fujii (1969, in [13]) & Japan & 800 & n.a. & $\begin{array}{l}\text { Event } \\
\text { (heavy rainfall) }\end{array}$ & $\begin{array}{l}\text { Cumulative frequency } \\
\text { distribution of } \\
\text { landslide scar areas }\end{array}$ & n.a. & n.a. & $0.96\left(\beta_{\mathrm{c}}\right) 1.96$ \\
\hline Hovius et al. [7] & $\begin{array}{l}\text { Southern Alps } \\
\text { (New Zealand) }\end{array}$ & 4984 & n.a. & $\begin{array}{l}\text { Historical } \\
\text { (LS }<60 \text { yr old) }\end{array}$ & $\begin{array}{l}\text { Annual cumulative } \\
\text { frequency distribution } \\
\text { of landslide scar areas } \\
\text { (logarithmic binning) }\end{array}$ & $4 \cdot 10^{-3}$ & $10^{-2}$ & $1.16\left(\beta_{\mathrm{c}}\right) 2.16$ \\
\hline Pelletier et al. $[8]^{\mathrm{b}}$ & $\begin{array}{l}\text { Akaishi Ranges } \\
\text { (Central Japan) }\end{array}$ & 3424 & n.a. & Historical & $\begin{array}{l}\text { Cumulative frequency } \\
\text { distribution of } \\
\text { landslide areas }\end{array}$ & n.a. & $10^{-1}$ & $2\left(\beta_{\mathrm{c}}\right) 3$ \\
\hline Pelletier et al. $[8]^{\mathrm{c}}$ & $\begin{array}{l}\text { Eastern Cordillera } \\
\text { (Bolivia) }\end{array}$ & n.a. & n.a. & Historical & $\begin{array}{l}\text { Cumulative frequency } \\
\text { distribution of } \\
\text { landslide areas }\end{array}$ & n.a. & $10^{-2}$ & $1.6-2\left(\beta_{\mathrm{c}}\right) 2.6-3$ \\
\hline Pelletier et al. $[8]^{\mathrm{d}}$ & $\begin{array}{l}\text { Northridge } \\
\text { (California, USA) }\end{array}$ & $>11000$ & 10000 & $\begin{array}{l}\text { Event } \\
\text { (earthquake) }\end{array}$ & $\begin{array}{l}\text { Cumulative frequency } \\
\text { distribution of landslide } \\
\text { areas }\end{array}$ & $2.0 \cdot 10^{-3}$ & $10^{-2}$ & $1.6\left(\beta_{\mathrm{c}}\right) 2.6$ \\
\hline $\begin{array}{l}\text { Malamud and Turcotte [9] } \\
\text { Guzzetti et al. [13] }]^{\mathrm{d}}\end{array}$ & $\begin{array}{l}\text { Northridge } \\
\text { (California, USA) }\end{array}$ & $>11000$ & 10000 & $\begin{array}{l}\text { Event } \\
\text { (earthquake) }\end{array}$ & $\begin{array}{l}\text { Non-cumulative } \\
\text { frequency } \\
\text { distribution of } \\
\text { landslide areas }\end{array}$ & $4.0 \cdot 10^{-4}$ & $10^{-3}$ & 2.3 \\
\hline Malamud and Turcotte $[9]^{\mathrm{b}}$ & $\begin{array}{l}\text { Akaishi Ranges } \\
\text { (Central Japan) }\end{array}$ & 3243 & n.a. & Historical & $\begin{array}{l}\text { Non-cumulative } \\
\text { frequency distribution } \\
\text { of landslide areas }\end{array}$ & $7.0 \cdot 10^{-2}$ & $10^{-1}$ & 3.0 \\
\hline Malamud and Turcotte $[9]^{c}$ & $\begin{array}{l}\text { Eastern } \\
\text { Cordillera } \\
\text { (Bolivia) }\end{array}$ & 1130 & n.a. & Historical & $\begin{array}{l}\text { Non-cumulative } \\
\text { frequency distribution } \\
\text { of landslide areas }\end{array}$ & $10^{-3}$ & $10^{-2}$ & 2.6 \\
\hline Malamud and Turcotte [9] & $\begin{array}{l}\text { Eden Canyon } \\
\text { (California, USA) }\end{array}$ & 709 & n.a. & Historical & $\begin{array}{l}\text { Non-cumulative } \\
\text { frequency distribution } \\
\text { of landslide areas }\end{array}$ & $2.0 \cdot 10^{-3}$ & $4 \cdot 10^{-3}$ & 3.3 \\
\hline Hovius et al. [10] & $\begin{array}{l}\text { Ma-an and Wan-li } \\
\text { catchments } \\
\text { (Taiwan) }\end{array}$ & 1040 & 378 & $\begin{array}{l}\text { Historical } \\
\text { (LS }<10 \text { yr old) }\end{array}$ & $\begin{array}{l}\text { Annual cumulative } \\
\text { frequency distribution } \\
\text { of landslide scar areas } \\
\text { (logarithmic binning) }\end{array}$ & n.a. & $8.0 \cdot 10^{-4}$ & $0.7\left(\beta_{\mathrm{c}}\right) 1.7$ \\
\hline Stark and Hovius $[11]^{\mathrm{f}}$ & $\begin{array}{l}\text { Western } \\
\text { southern Alps } \\
\text { (New Zealand) }\end{array}$ & 5086 & n.a. & Historical & $\begin{array}{l}\text { Double Pareto } \\
\text { probability distribution } \\
\text { (non-cumulative and } \\
\text { logarithmic binning) }\end{array}$ & $1.8 \cdot 10^{-3}$ & $10^{-2}$ & 2.44 \\
\hline
\end{tabular}




\begin{tabular}{|c|c|c|c|c|c|c|c|c|}
\hline Stark and Hovius $[11]^{\mathrm{f}}$ & $\begin{array}{l}\text { Whataroa catchment } \\
\text { in Western southern } \\
\text { Alps (New Zealand) }\end{array}$ & 3986 & n.a. & Historical & $\begin{array}{l}\text { Double Pareto } \\
\text { probability distribution } \\
\text { (non-cumulative and } \\
\text { logarithmic binning) }\end{array}$ & $8.0 \cdot 10^{-4}$ & $10^{-2}$ & 2.48 \\
\hline Martin et al. [12] & $\begin{array}{l}\text { Queen Charlotte } \\
\text { Isl (Canada) }\end{array}$ & 615 & 167 & $\begin{array}{l}\text { Historical } \\
\text { (LS < 40 yr old) }\end{array}$ & $\begin{array}{l}\text { Annual non-cumulative } \\
\text { probability distribution } \\
\text { of landslide areas } \\
\text { (mainly shallow } \\
\text { landslides) }\end{array}$ & $8.0 \cdot 10^{-4}$ & $10^{-3}$ & 1.8 \\
\hline Guzzetti et al. [13] & $\begin{array}{l}\text { Umbria Marche } \\
\text { (Italy) }\end{array}$ & 16809 & 18000 & Historical & $\begin{array}{l}\text { Non-cumulative } \\
\text { frequency distribution } \\
\text { of landslide areas } \\
\text { (derivative method) }\end{array}$ & $2.0 \cdot 10^{-2}$ & $10^{-1}$ & 2.5 \\
\hline Guzzetti et al. [13] & $\begin{array}{l}\text { Umbria Marche } \\
\text { (Italy) }\end{array}$ & 4233 & 2000 & $\begin{array}{l}\text { Event (rapid } \\
\text { snow melt) }\end{array}$ & $\begin{array}{l}\text { Non-cumulative } \\
\text { frequency distribution } \\
\text { of landslide areas } \\
\text { (derivative method) }\end{array}$ & $4.0 \cdot 10^{-4}$ & $10^{-3}$ & 2.5 \\
\hline Crosta et al. [14] & $\begin{array}{l}\text { Valtellina } \\
\text { (Central Alps, } \\
\text { Northern Italy) }\end{array}$ & 260 & 270 & $\begin{array}{l}\text { Event } \\
\text { (Rainfall) }\end{array}$ & $\begin{array}{l}\text { Non-cumulative } \\
\text { frequency distribution } \\
\text { of landslide areas } \\
\text { (shallow landslides in } \\
\text { terraced areas) }\end{array}$ & n.a. & $7.0 \cdot 10^{-5}$ & 1.85 \\
\hline Iwahashi et al. [15] & $\begin{array}{l}\text { Higashikubiki } \\
\text { (Japan) }\end{array}$ & 6083 & n.a. & Historical & $\begin{array}{l}\text { Double Pareto } \\
\text { probability } \\
\text { distribution (non- } \\
\text { cumulative and with } \\
\text { logarithmic binning) }\end{array}$ & n.a. & $10^{-2}$ & 2.11 \\
\hline Guthrie and Evans [16] & $\begin{array}{l}\text { Brooks Peninsula } \\
\text { (Vancouver Isl, } \\
\text { Canada) }\end{array}$ & 201 & 286 & Historical & $\begin{array}{l}\text { Double Pareto } \\
\text { probability } \\
\text { distribution (non- } \\
\text { cumulative and with } \\
\text { logarithmic binning) }\end{array}$ & $7.0 \cdot 10^{-3}$ & $2.0 \cdot 10^{-2}$ & 2.17 \\
\hline Guthrie and Evans [16] & $\begin{array}{l}\text { Brooks Peninsula } \\
\text { (Vancouver Isl, } \\
\text { Canada) }\end{array}$ & 136 & 286 & $\begin{array}{l}\text { Historical } \\
\text { (LS }<60 \text { yr old) }\end{array}$ & $\begin{array}{l}\text { Double Pareto } \\
\text { probability distribution } \\
\text { (non-cumulative and } \\
\text { with logarithmic } \\
\text { binning) }\end{array}$ & $7.4 \cdot 10^{-3}$ & $2.0 \cdot 10^{-2}$ & 2.77 \\
\hline Guthrie and Evans $[16,17]$ & $\begin{array}{l}\text { Loughborough } \\
\text { (Vancouver Isl, } \\
\text { Canada) }\end{array}$ & 92 & 370 & $\begin{array}{l}\text { Event } \\
\text { (storm) }\end{array}$ & $\begin{array}{l}\text { Double Pareto } \\
\text { probability distribution } \\
\text { (non-cumulative and } \\
\text { with logarithmic } \\
\text { binning) }\end{array}$ & $9.3 \cdot 10^{-3}$ & $3.0 \cdot 10^{-2}$ & 2.51 \\
\hline
\end{tabular}


Table 1 (continued)

\begin{tabular}{|c|c|c|c|c|c|c|c|c|}
\hline \multirow[t]{3}{*}{ Reference $^{a}$} & \multirow[t]{3}{*}{ Location } & \multirow{3}{*}{$\begin{array}{l}\text { Number } \\
\text { of LS }\end{array}$} & \multirow{3}{*}{$\begin{array}{l}\text { Size of } \\
\text { study area } \\
\left(\mathrm{km}^{2}\right)\end{array}$} & \multirow{3}{*}{$\begin{array}{l}\text { Type of } \\
\text { inventory }\end{array}$} & \multicolumn{4}{|l|}{ Relation } \\
\hline & & & & & & \multirow{2}{*}{$\begin{array}{l}\text { Location } \\
\text { rollover } \\
\left(t ; \mathrm{km}^{2}\right)\end{array}$} & \multicolumn{2}{|c|}{$\begin{array}{l}\text { Negative power-law for medium and } \\
\text { large LS }\end{array}$} \\
\hline & & & & & & & $\begin{array}{l}\text { Starting at } A_{\mathrm{L}} \\
\left(\mathrm{km}^{2}\right)\end{array}$ & $\begin{array}{l}\text { Exponent } \\
(\beta)\end{array}$ \\
\hline $\begin{array}{l}\text { Guthrie and Evans [16] } \\
\text { Evans et al. [43] }\end{array}$ & $\begin{array}{l}\text { Clayoquot } \\
\text { (Vancouver Isl, } \\
\text { Canada) }\end{array}$ & 1009 & n.a. & Historical & $\begin{array}{l}\text { Double Pareto } \\
\text { probability distribution } \\
\text { (non-cumulative and } \\
\text { with logarithmic } \\
\text { binning) }\end{array}$ & $5.2 \cdot 10^{-3}$ & $5.0 \cdot 10^{-2}$ & 2.54 \\
\hline Brardinoni and Church [18] & $\begin{array}{l}\text { Capilano watershed } \\
\text { (Canada) }\end{array}$ & $\begin{array}{l}2984 \\
\text { (small are } \\
\text { estimated) }\end{array}$ & 198 & Historical & $\begin{array}{l}\text { Non-cumulative } \\
\text { frequency distribution } \\
\text { of landslide volumes } \\
\text { (derivative method) }\end{array}$ & $\begin{array}{l}4.0 \cdot 10^{-3} \\
\text { For smaller } \\
\text { LS: negative } \\
\text { power-law } \\
\beta_{\mathrm{vol}}=1.0 \\
\beta=1 \mathrm{~g}\end{array}$ & $4.0 \cdot 10^{-3}$ & $3.5\left(\beta_{\mathrm{vol}}\right) 3.5^{\mathrm{g}}$ \\
\hline Malamud et al. $[19]^{\mathrm{d}}$ & $\begin{array}{l}\text { Northridge } \\
\text { (California, USA) }\end{array}$ & 11111 & 10000 & $\begin{array}{l}\text { Event } \\
\text { (earthquake) }\end{array}$ & $\begin{array}{l}\text { Three parameter } \\
\text { inverse-gamma } \\
\text { probability distribution } \\
\text { (logarithmic binning) }\end{array}$ & $4.0 \cdot 10^{-4}$ & $10^{-3}$ & 2.4 \\
\hline Malamud et al. [19] ${ }^{e}$ & $\begin{array}{l}\text { Umbria Marche } \\
\text { (Italy) }\end{array}$ & 4233 & 2000 & $\begin{array}{l}\text { Event (rapid } \\
\text { snow melt) }\end{array}$ & $\begin{array}{l}\text { Three parameter } \\
\text { inverse-gamma } \\
\text { probability distribution } \\
\text { (logarithmic binning) }\end{array}$ & $4.0 \cdot 10^{-4}$ & $10^{-3}$ & 2.4 \\
\hline Malamud et al. [19] & Guatemala & 9594 & 10000 & $\begin{array}{l}\text { Event } \\
\text { (rainfall, } \\
\text { hurricane) }\end{array}$ & $\begin{array}{l}\text { Three parameter } \\
\text { inverse-gamma } \\
\text { probability distribution } \\
\text { (logarithmic binning) }\end{array}$ & $4.0 \cdot 10^{-4}$ & $10^{-3}$ & 2.4 \\
\hline Korup [21] & $\begin{array}{l}\text { Southwest New } \\
\text { Zealand }\end{array}$ & 778 & 18672 & Historical & $\begin{array}{l}\text { Frequency density of } \\
\text { landslide area }\end{array}$ & $3.2 \cdot 10^{-2}$ & $3.2 \cdot 10^{-2}$ & 2.55 \\
\hline Catani et al. [22] & Arno River basin & 27500 & 9100 & Historical & $\begin{array}{l}\text { Frequency density of } \\
\text { landslide area }\end{array}$ & $10^{-3}-10^{-2}$ & $10^{-2}$ & 3.36 \\
\hline Havenith et al. [24] & $\begin{array}{l}\text { Mailuu-Suu } \\
\text { (Kyrgyztan) }\end{array}$ & 220 & 530 & Historical & $\begin{array}{l}\text { Frequency density of } \\
\text { landslide area }\end{array}$ & $2-3 \cdot 10^{-3}$ & $3 \cdot 10^{-3}$ & 1.90 \\
\hline Chien-Yuan et al. [25] & $\begin{array}{l}\text { Shihman watershed } \\
\text { (Northern Taiwan) }\end{array}$ & n.a. & n.a. & $\begin{array}{l}\text { Historical } \\
\text { (Typhoon+ } \\
\text { earthquake) }\end{array}$ & $\begin{array}{l}\text { Non-cumulative } \\
\text { frequency distribution } \\
\text { of landslide areas } \\
\text { (mainly shallow debris } \\
\text { flows) }\end{array}$ & $3 \cdot 10^{-3}$ & $10^{-2}$ & 1.65 \\
\hline
\end{tabular}


of landslide areas

(mainly shallow debris

flows)

Chien-Yuan et al. [25]

Chushui watershed

n.a.

8.6

Event

(Typhoon,

Non-cumulative

$10^{-3}$

frequency distribution

of landslide areas

(mainly shallow debris

flows)

Chien-Yuan et al. [25]

Chushui watershed

n.a.

8.6

Event

Non-cumulative

$10^{-3}$

frequency distribution

2004) of landslide areas

(mainly shallow debris

flows) 
involving $S$ grains of sand. Eventually, the slope will settle around the angle of repose. Then, most avalanches will be limited in size, but large events are also likely to occur. More specifically, Bak et al. [26] found a powerlaw relation between the number of avalanches involving $S$ grains, $f(S)$, and the number of grains, $S$ (i.e. $f(S) \approx S^{-\beta}$ ). A computer simulation in which the sand pile was simulated in a $2 \mathrm{D}$ grid, each grid cell representing the force acting on a particle at that site, resulted in the same power-law distribution [28].

In the case of LS, the power-law portion of the frequency density function describes inherent LS limitations because possible locations where LS can occur decrease with LS size. On average, power-law relations through medium-sized and large LS areas have an exponent $-\beta$ of $-2.3 \pm 0.6$ (Table 1). The smaller the exponent $\beta$, the more important the contribution of the larger LS to the total inventory is, and vice versa. The large scatter observed around the average $\beta$ value (Table 1) is partly related to differences in environmental factors $[13,15]$. For the studies listed, however, this relationship between the exponent $\beta$ and the environmental factors is not straightforward as no differences in environmental factors can e.g. explain why, compared to the other LS inventories, for the LS inventory of Taiwan a low exponent (i.e. $\beta=1.7 ;[10]$ ) was obtained. Similar to all other inventories, the frequency distribution is derived for LS in an active mountain belt, where lithology is characterized by bed rock overlain with a thin regolith cover.

Many distributions, however, have two scaling regimes: the aforementioned negative power-law scaling for medium-sized and large LS, and a positive power-law scaling for small LS. According to Guzzetti et al. [13] the transition between these regimes, the rollover, is located at the transition between resistances against slope failure controlled by friction or by cohesion, which are the case for large, deep-seated and small, shallow LS respectively. For 'complete' event LS inventories, the rollover is accepted to be a physical manifestation of conditions of LS occurrence $[8,10,13]$, because it is located within LS areas which are larger than the smallest LS area that is consistently mapped. When comparing the average location of the rollover $(t)$ in the frequency distributions compiled in Table 1 for event (i.e. $2.0 \cdot 10^{-3} \pm 3.5 \cdot 10^{-3} \mathrm{~km}^{2}$ ) and historical (i.e. $1.1 \cdot 10^{-2} \pm 1.8 \cdot 10^{-2} \mathrm{~km}^{2}$ ) inventories, the rollover of the latter group generally shifts to larger area values. For historical LS inventories, the positive relation between LS area and frequency for small LS is explained by the incompleteness of the inventory due to erosion and to limitations of reconnaissance mapping techniques [13,19].

For populated hilly regions, frequency distributions of LS areas have rarely been investigated. As these regions have tectonical and geomorphological characteristics different from those of mountainous areas and are generally more affected by human interventions, the frequency distribution will not necessarily be similar to those summarized in Table 1. Therefore this study investigates the frequency-area distribution of a historical LS inventory in a hilly region. More specifically (1) the frequency-area distribution will be investigated for a $430 \mathrm{~km}^{2}$ study area in the Flemish Ardennes; (2) the obtained distribution will be compared to those obtained for LS inventories in mountainous areas; (3) a conceptual model for frequency-area distributions of LS in populated hilly areas will be presented, and (4) the results of Malamud et al. [19] will be used to estimate the total number of LS, and their affected area, that have occurred in the study area over time.

\section{Materials and methods}

\subsection{Study area}

For this study a LS inventory for a $430 \mathrm{~km}^{2}$ study area in the Flemish Ardennes (Fig. 1) was used. This hilly region has a maritime temperate climate with a mean annual rainfall of $800 \mathrm{~mm}$, which is well-distributed over all seasons. The regional topography, lithology and hydrology are important environmental factors controlling slope stability [4]. The Flemish Ardennes is characterized by altitudes ranging from 10 masl in the valley of the river Scheldt to 150 masl on the Tertiary hills, located east of the river Scheldt. Hillslope gradients are generally less than $0.15 \mathrm{~m} \mathrm{~m}^{-1}$. Due to the systematic valley asymmetry, slopes facing from south through to northwest are steeper than slopes facing to other directions. Several active faults are suspected within and at the boundaries of this region [31]. Different to the mountainous areas described in Table 1, lithology consists of alternations of sub-horizontal, loose Tertiary silty or clayey sand layers and clay layers, which are overlain by Quaternary eolian loess of varying thickness $[32,33]$. Due to the alternation of more permeable clayey sand layers and almost impermeable clay layers perched water tables build up, and springs occur where water tables intersect the topography. Cropland is located on the loess-covered plateaus of the lower hills, and pastures dominate the hillslopes. The highest loess-free Tertiary hills and the steepest hillslopes are forested [34].

\subsection{Landslide inventory}

As $85 \%$ of the LS are partly or completely covered by forest, aerial photo interpretation was not an appropriate mapping method, because only a few recently reactivated LS were visible on these aerial photographs. Instead, LS 
were mapped during an intensive field survey that took place during the winters of 2002-2003 and 2003-2004 [2]. The total study area, with exception of flatter areas where no LS were expected, was checked for the presence of LS. In the field, LS were drawn on the topographical map $(1: 10000 ;[35])$, because the problem of using GPS in forested areas [36] disabled the mapping of LS with GPS. Back in the office, the mapped LS were stored in a GIS environment (MapInfo).

More recently, accurate topographical data measured with Light Detection and Ranging (LIDAR) became available for the region [37]. From the $x, y$, and $z$ values of measuring points, corrected for canopy and building returns, with an approximate density of 1 point per $20 \mathrm{~m}^{2}$ and a vertical accuracy between 7 and $20 \mathrm{~cm}$, a DEM with a $5 \mathrm{~m}$ resolution was created in IDRISI Kilimanjaro. First, a Triangulated Irregular Network (TIN) model was generated using Delauney Triangulation. This TIN was then used to create the DEM with a $5 \mathrm{~m}$ resolution, and from this DEM hillshade and contour maps were derived. Both hillshade maps and contour maps were analysed for the presence of LS, and the boundaries of LS already mapped in the field were checked, and corrected if necessary. More information on the LIDAR data used and landslide mapping can be found in Van Den Eeckhaut et al. [3]

In total the inventory comprises $217 \mathrm{LS}$. Together they cover $6.57 \mathrm{~km}^{2}$ or $1.5 \%$ of the $430 \mathrm{~km}^{2}$ study area. In the field, they were further subdivided in 153 deep-seated LS with an estimated shear surface deeper than $3 \mathrm{~m}$, and in 64 shallow LS with an estimated shear surface less than $3 \mathrm{~m}$ deep (e.g. Fig. 2). Deep-seated LS are generally (i.e. in $85 \%$ of the cases) larger than 1 ha. Most of these slides are classified as rotational earth slides. Although little is known about their age, they are assumed to be older than $100 \mathrm{yr}$ as no historical document describing their initiation is found. Recently, AMS radiocarbon dating of one LS suggests that landsliding occurred as early as $7800 \mathrm{BP}$ [38]. Hence, their initiation and reactivation can be related to pre-or Early Holocene environmental conditions. Shallow LS, on the other hand, are generally smaller than 1 ha, and are complex earth slides. They start as rotational earth slides, but their foot has flow characteristics. Some of them are located within a deep-seated LS (Fig. 2C). These shallow LS were generally initiated during the last $30 \mathrm{yr}$ after long periods of rainfall, often on hillslope sections where local human activities decreasing slope stability (e.g. removal of lateral
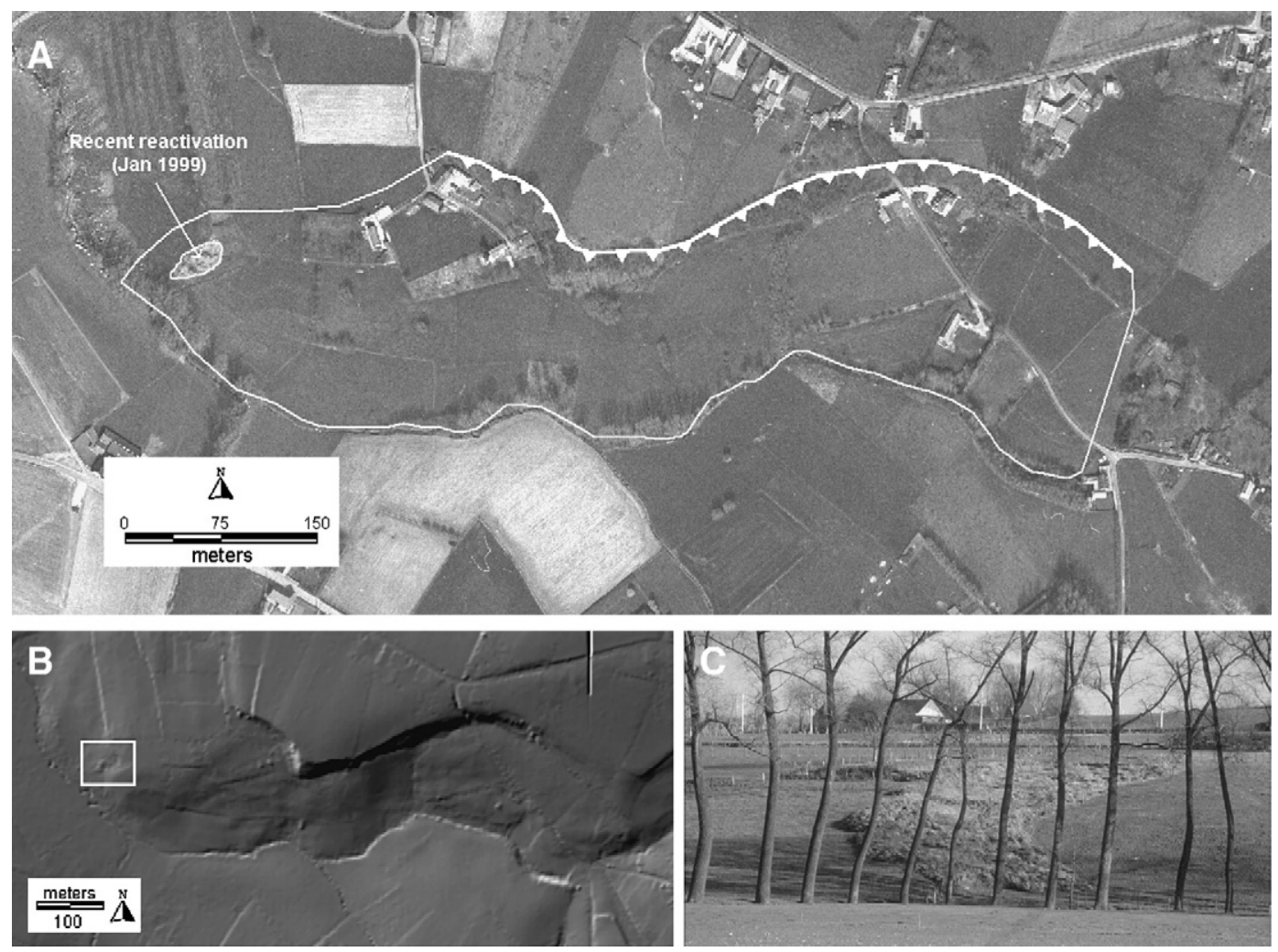

Fig. 2. Old deep-seated landslide in the study area (Schorisse, Maarkedal) with indication of a shallow complex earth slide that was initiated during the winter of 1998-1999: (A) Orthophoto [42]. (B) LIDAR-derived hillshade map [37]. The white rectangle indicates the location of the reactivation; (C) Recent reactivation in 2000. See (A) for location on orthophoto. 
support at LS foot or overloading of LS depletion area for construction works, poor and insufficient sewerage systems, obstruction of springs) had been carried out [5].

\subsection{Estimation of total number of landslides that occurred over time in the study area, and their affected area}

Malamud et al. [19] investigated the frequency-area distribution of three 'substantially different and complete' LS inventories (Table 1). They were considered to be 'substantially different' because in all cases the LS were initiated by a different triggering factor, being heavy rainfall, earthquake shaking and snow melt, and in a different mountainous area of the world, i.e. Guatemala, California and Italy respectively. All three inventories contained shallow and deep-seated LS, mainly soil slides and soil flows, but shallow LS were more abundant. As the inventories were created shortly after the triggering event took place, when the LS were still fresh, they were also considered as being complete for LS larger than $225 \mathrm{~m}^{2}$. Malamud et al. [19,20] found that the three complete inventories were all approximated by the same probability density function, $p\left(A_{L}\right)$, i.e. a three-parameter inverse-gamma probability distribution.

$$
\begin{aligned}
p\left(A_{\mathrm{L}} ; \rho, a, s\right) & =\left(\frac{1}{N_{\mathrm{LT}}} \frac{\delta N_{\mathrm{L}}}{\delta A_{\mathrm{L}}}\right) \\
& =\frac{1}{a \Gamma(\rho)}\left[\frac{a}{A_{\mathrm{L}}-s}\right]^{\rho+1} \exp \left[-\frac{a}{A_{\mathrm{L}}-s}\right]
\end{aligned}
$$

where

$A_{\mathrm{L}} \quad$ is the area $\left(\mathrm{km}^{2}\right)$ occupied by an individual LS; $\rho \quad$ is a parameter controlling the power-law decay for medium-sized and large LS;

$a$ is a parameter controlling the location of the maximum probability distribution;

$s \quad$ is a parameter controlling the exponential rollover for small LS areas

$N_{\mathrm{LT}} \quad$ is the total number of LS in an inventory;

$\delta N_{\mathrm{L}} / \delta A_{\mathrm{L}}\left(\mathrm{km}^{-2}\right)$ is the number of LS with areas between $A_{\mathrm{L}}$ and $A_{\mathrm{L}}+\delta A_{\mathrm{L}} . \delta A_{\mathrm{L}}$ increased with increasing $A_{\mathrm{L}}$, so that bin widths are approximately equal in logarithmic coordinates; and

$\Gamma(\rho)$ is the gamma function of $\rho$.

The inverse-gamma distribution is an inverse powerlaw decay with an exponent $-(\rho+1)$ for medium and large areas, and an exponential rollover for small areas. Note that for distributions approximated by the threeparameter inverse-gamma probability distribution $-(\rho+1)=-\beta$ (Table 1). Malamud et al. [19] obtained $\rho=1.4 ; \quad a=1.28 \cdot 10^{-3} \mathrm{~km}^{2}, \quad s=-1.32 \cdot 10^{-4} \mathrm{~km}^{2}$, $\Gamma(1.4)=0.88726$, and a coefficient of determination $r^{2}=0.965$. Hence, the exponent $-(\rho+1)$ has a value of -2.4 , which is comparable to the average exponent of -2.3 obtained for the studies compiled in Table 1, and the maximum probability distribution is located at $A_{\mathrm{L}}=4.0 \cdot 10^{-4} \mathrm{~km}^{2}$. The graph corresponding to this 'general' equation is shown in Fig. 3A. By taking the first moment of Eq. (1), the theoretical mean LS area was calculated to be $3.07 \cdot 10^{-3} \mathrm{~km}^{2}$.

Similar to the Gutenberg-Richter scale for earthquakes and the LS magnitude scale defined by Keefer [39], Malamud et al. [19] also proposed a LS magnitude scale $m_{\mathrm{L}}$ for complete LS inventories:

$m_{\mathrm{L}}=\log _{10}\left(N_{\mathrm{LT}}\right)$

where $N_{\mathrm{LT}}$ is the total number of LS associated with the triggering event. According to this equation, an event triggering between 10 and $100 \mathrm{LS}$ has a $m_{\mathrm{L}}$ between 1 and 2. However, LS inventories corresponding to one single event are generally restricted to a relatively narrow magnitude range between 3 and 4 .

Malamud et al. [19] used the analyses presented above to extrapolate historical and therefore incomplete LS inventories to obtain the total number of LS and the total area affected by these LS. Historical LS inventories are the sum of single to many LS events that occurred over time in a certain region, and all of these individual events are believed to satisfy the general LS probability distribution (Eq. (1)). Hence, the sum of all these events is expected to also satisfy this distribution. As the total number of LS that have occurred over time $\left(N_{\mathrm{LT}}\right)$ is not known for incomplete LS inventories, the probability density function (Eq. (1)) cannot be calculated. It is, however, possible to calculate the frequency density, $f\left(A_{\mathrm{L}}\right)\left(\mathrm{km}^{-2}\right)$ :

$f\left(A_{\mathrm{L}}\right)=\frac{\delta N_{\mathrm{L}}}{\delta A_{\mathrm{L}}}$

where $\delta N_{\mathrm{L}} / \delta A_{\mathrm{L}}\left(\mathrm{km}^{-2}\right)$ is the number of LS with areas between $A_{\mathrm{L}}$ and $A_{\mathrm{L}}+\delta A_{\mathrm{L}}$. Combining Eqs. (1) and (3) results in:

$f\left(A_{\mathrm{L}}\right)=N_{\mathrm{LT}} \cdot p\left(A_{\mathrm{L}}\right)$.

Eq. (4) indicates that $f\left(A_{\mathrm{L}}\right)$ can be obtained by multiplying $p\left(A_{\mathrm{L}}\right)$ with the $N_{\mathrm{LT}}$ corresponding to different LS magnitudes (Eq. (2)). Fig. 3B shows theoretical curves of $f\left(A_{\mathrm{L}}\right)$ for $m_{\mathrm{L}}$ ranging from 1 to 5 , which correspond with $N_{\mathrm{LT}}$ values of 10 to $100000 \mathrm{LS}$. The frequency densities of the three complete inventories used by Malamud et al. [19], and of a hypothetical 
(i.e. not based on a true landslide inventory) historical and incomplete LS inventory similar to the ones reported by Malamud et al. [19] are also shown.

As mentioned in the Introduction and shown in Fig. 3B, historical inventories still exhibit a power-law tail with an
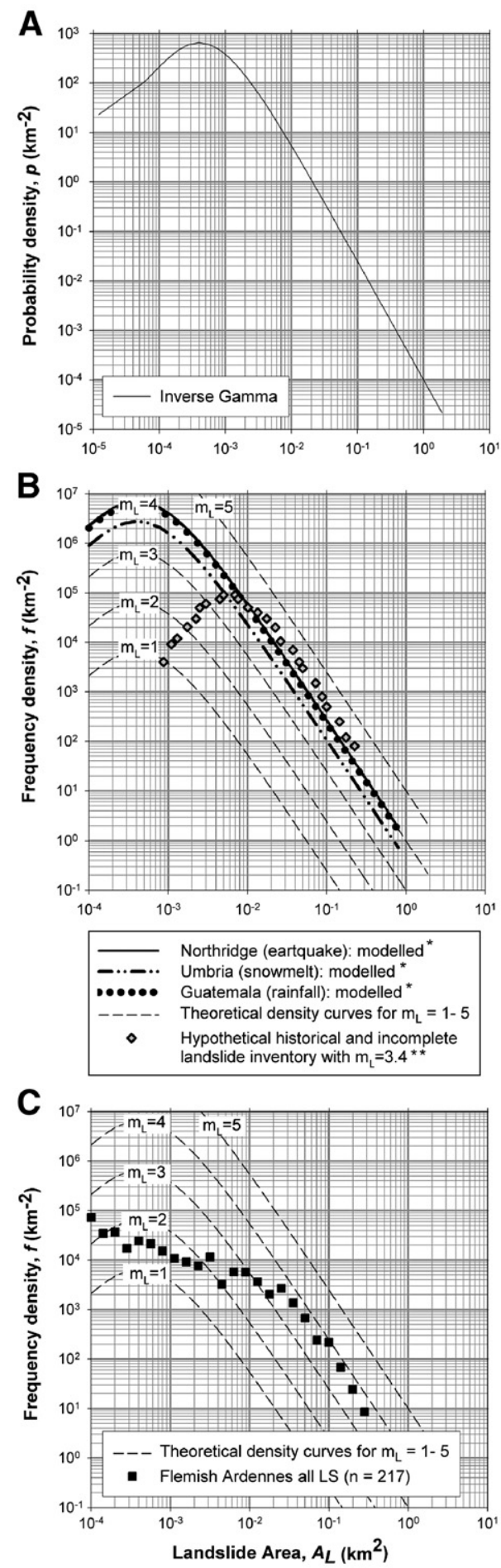

exponent $-\beta$ of approximately -2.4 , but the power-law tail generally starts from larger areas. For smaller areas, the rollover is obtained, but its location has also shifted to the lower right. Both the start of the power-law tail at larger LS areas, and the deviation from the rollover for smaller LS areas is attributed to the incompleteness of the LS inventory. The position of the power-law tail allows the estimation of the LS magnitude $\left(m_{\mathrm{L}}\right)$, and (with Eq. (2)) the corresponding total number of LS $\left(N_{\mathrm{LT}}\right)$. Multiplication of the total number of LS with the theoretical mean LS area of $3.07 \cdot 10^{-3} \mathrm{~km}^{2}$, finally provides an idea of the total area affected by LS. We created an artificial historical inventory to illustrate this method. For this hypothetical inventory (Fig. 3B), the rollover has shifted from $A_{\mathrm{L}}=4.0 \cdot 10^{-4} \mathrm{~km}^{2}$ for complete event LS inventories to $A_{\mathrm{L}}=7.0 \cdot 10^{-3} \mathrm{~km}^{2}$, and the power-law tail starts from ca. $2 \cdot 10^{-2} \mathrm{~km}^{2}$. This power-law tail suggests a magnitude of ca. 4.4 which corresponds to ca. 25100 (i.e. $10^{4.4}$ ) LS, and a total affected area of ca. $77 \mathrm{~km}^{2}$.

The LS inventory obtained for the Flemish Ardennes is an example of an incomplete historical inventory. Even though the methodology presented above is only approximate, it will be used to estimate the total number and area of LS that have occurred in the Flemish Ardennes over time. Therefore, all LS mapped in the field, were classified according to their size. Similar to Malamud et al. [19] class intervals are equal on a logarithmic scale. Then the number of LS in each class was divided by the bin width corresponding to that class, and the value obtained for each class was plotted against the lower area boundary of the class (i.e. $A_{\mathrm{L}}$ ) to obtain the frequency density.

\section{Results}

\subsection{Frequency distribution of landslide areas in the Flemish Ardennes}

For the LS inventory of the Flemish Ardennes, including 217 LS (Table 2), the frequency density $f\left(A_{\mathrm{L}}\right)$

\footnotetext{
Fig. 3. (A) General landslide probability distribution: the best fit obtained by Malamud et al. [19] to three landslide inventories of the three-parameter inverse-gamma distribution (Eq. (1) with $\rho=1.4$; $a=1.28 \cdot 10^{-3} \mathrm{~km}^{2}, s=-1.32 \cdot 10^{-4} \mathrm{~km}^{2}$ ); (B) Dependence of landslide frequency density, $f$, on landslide area, $A_{\mathrm{L}}$. Landslide frequency distributions corresponding to the general landslide probability distribution (Eq. (1)) proposed by Malamud et al. [19] are given for landslide magnitude (Eq. (2)), $m_{\mathrm{L}}=1,2,3,4$ and $5\left(N_{\mathrm{LT}}=10^{1}, 10^{2}, \ldots\right.$, $\left.10^{5}\right)$. The modelled frequency density curves for the three landslide inventories analysed by Malamud et al. ([19]; *) and the frequency density of a hypothetical historical landslide inventory similar to the ones reported by Malamud et al. ([19]; **) are also shown; (C) Dependence of landslide frequency density, $f$, on landslide area, $A_{\mathrm{L}}$, for the landslide inventory of the Flemish Ardennes.
} 
Table 2

Number of landslides mapped in the study area by size and age

\begin{tabular}{lll}
\hline Criterion & $\begin{array}{l}\text { Number } \\
\text { of LS }(n)\end{array}$ \\
\hline All LS recorded in Flemish Ardennes & 217 \\
Size & Small (i.e. $A_{\mathrm{L}}<0.02 \mathrm{~km}^{2}$ ) LS & 130 \\
& Medium and large (i.e. $A_{\mathrm{L}}>0.02 \mathrm{~km}^{2}$ ) LS & 87 \\
Age & Recently (i.e. generally $<30$ yr) active LS & 56 \\
& Old (i.e. generally $>30$ yr) dormant LS & 161 \\
\hline
\end{tabular}

is shown in Fig. 3C. Areas occupied by individual LS range between $10^{-4}$ and $3 \cdot 10^{-1} \mathrm{~km}^{2}$. Similar to the incomplete inventories investigated by Malamud et al [19] and the hypothetical curve shown in Fig. 3B, the distribution of the smaller $\mathrm{LS}$ areas (i.e. $A_{\mathrm{L}}<1-$ $2 \cdot 10^{-2} \mathrm{~km}^{2}$ ) in the Flemish Ardennes deviates from the theoretical curves (indicated with dashed lines in Fig. 3B, C), while the power-law tail is in good agreement for $87 \mathrm{LS}$ with an area larger than $2 \cdot 10^{-2} \mathrm{~km}^{2}$. The exponent $-\beta$ of -2.31 obtained for the power regression model through these $87 \mathrm{LS}$ (Fig. 4A) also corresponds well with the average value of 2.3 calculated from previous studies (Table 1 ). In the study area, the size of LS with $A_{\mathrm{L}}>1-2 \cdot 10^{-2} \mathrm{~km}^{2}$ is restricted by the local geomorphology; especially by the LS length. Large LS generally start at the steepest section along the hillslope, which usually corresponds with the outcrop of a ca. $10 \mathrm{~m}$ homogenous clay layer located on the mid slope, and end in the valley. Therefore LS become more rare with increasing size, and in combination with larger LS classes, which is related to the logarithmic scale, this results in the higher exponent $-\beta$ of -2.31 for the regression line.

Different to Malamud et al. [19], however, is that the distribution of the smaller LS (i.e. $A_{\mathrm{L}}<1-2 \cdot 10^{-2} \mathrm{~km}^{2}$ ) in the Flemish Ardennes is not characterized by a
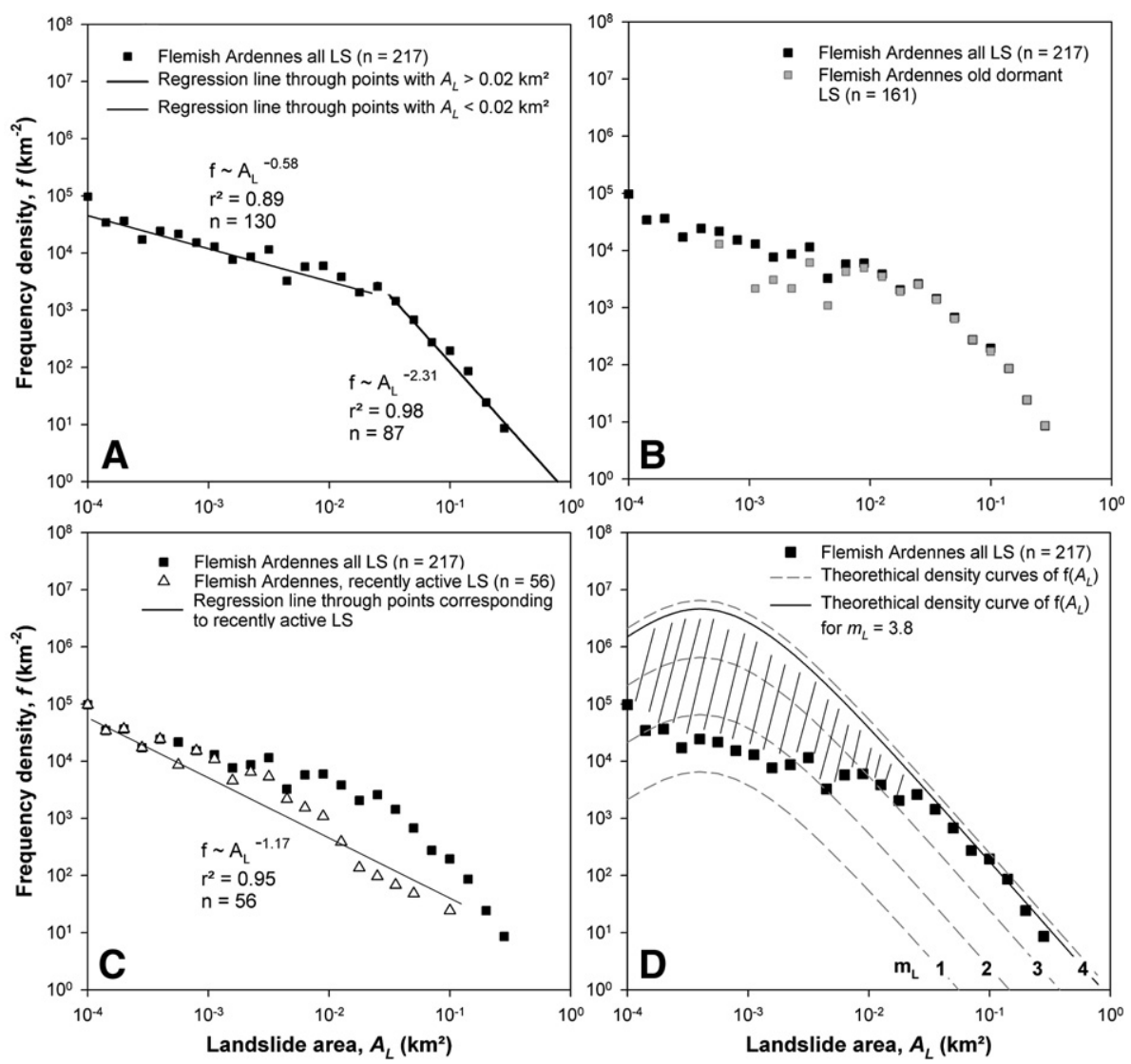

Fig. 4. Landslide frequency density, $f$, as a function of landslide area, $A_{\mathrm{L}}$, for the historical inventory of the $430 \mathrm{~km}^{2}$ study area in the Flemish Ardennes: (A) $f\left(A_{\mathrm{L}}\right)$ is best approximated by two negative power-law relations; (B) Same as (A) but with $f\left(A_{\mathrm{L}}\right)$ for the landslide inventory without landslides that occurred during the last 20 to $30 \mathrm{yr}$; (C) Same as (A) but with $f\left(A_{\mathrm{L}}\right)$ for the landslide inventory without landslides older than 20 to $30 \mathrm{yr}$; (D) Estimate of total number of landslides that have occurred over time using the approach suggested by Malamud et al. [19]. Dashed line represents the theoretical density curve for a landslide magnitude $m_{\mathrm{L}}=3.8$, which is the upper limit of the landslide magnitude of the historical landslide inventory compiled for the study area. Hatched area represents the number of landslides not observed in the field. 
positive power-law relation which is separated from medium-sized to large LS by a rollover. Instead, the frequency distribution of the LS with affected areas below ca. $1-2 \cdot 10^{-2} \mathrm{~km}^{2}$ is best described by a negative power function with an exponent $-\beta$ of -0.58 (Fig. 4A). The transition between the two negative power-law relations is situated around $10^{-2} \mathrm{~km}^{2}$. This critical $A_{\mathrm{L}}$ value is used in this study together with a critical depth of the surface of rupture of $3 \mathrm{~m}$ (see Section 2.1) to distinguish between small, shallow and large, deepseated LS. Hence, Fig. 4A suggests that the frequency distribution of $A_{\mathrm{L}}$ reflects the occurrence of two LS populations with different size characteristics (i.e. different LS affected area and LS depth).

However, as most deep-seated LS are old, and most shallow LS occurred more recently outside or inside an existing LS, it is possible that the age of the LS controls the frequency distribution of $A_{\mathrm{L}}$. Therefore, the frequency distribution of old $(n=161)$ and recent $(n=56)$ LS are shown separately in Fig. 4B and C respectively. Apart from two LS recorded in 1904 [40] and 1926 [41], all recent LS events are younger than ca. 30 yr. They can be newly initiated or reactivated within an old landslide. In the latter case significant displacements of decimetres to tens of metres were observed. Older landslides where slow creep processes are active within the landslide foot are not considered as recent. Dropping one outlier at $A_{\mathrm{L}}=5.6 \cdot 10^{-4} \mathrm{~km}^{2}$, the distribution of the old LS (Fig. 4B) is similar to the hypothetical LS inventory shown in Fig. 3B, i.e. it has a rollover around $A_{\mathrm{L}}=10^{-2} \mathrm{~km}^{2}$ and a power-law relation for larger LS (i.e. $A_{\mathrm{L}}>2 \cdot 10^{-2} \mathrm{~km}^{2}$ ). The distribution of the recent LS (Fig. 4C), on the other hand, is best described by a negative power regression model with an exponent -1.17 for $A_{\mathrm{L}}$ between $10^{-4}$ and $7 \cdot 10^{-2} \mathrm{~km}^{2}$.

\subsection{Estimation of total number of landslides that occurred over time in the study area, and their affected area}

Given that the frequency distribution of $A_{\mathrm{L}}$ for old, large, deep-seated LS in the Flemish Ardennes is similar to the theoretical frequency density curves, the approach suggested by Malamud et al. [19] was applied to the compiled LS inventory. The exponent of -2.31 obtained for the power-law tail through LS with an area larger than $2 \cdot 10^{-2} \mathrm{~km}^{2}$ in the Flemish Ardennes suggests a LS magnitude $m_{\mathrm{L}}$ of $3.7 \pm 0.1$ (Fig. 4D), which corresponds according to Eq. (2) with an estimated total number of LS $\left(N_{\mathrm{LT}}\right)$ of $5150 \pm 1165$. This estimate suggests that the 217 mapped LS represent less than $5 \%$ of the total number of LS that have occurred in the study area, and that about $95 \%$ of all LS initiated in the study area, especially the small old ones, have been obliterated by soil erosion or by human activities. By multiplying the estimated total number of LS with the mean LS area of $3.07 \cdot 10^{-3} \mathrm{~km}^{2}$ obtained by Malamud et al. [19], the total area affected by LS in the Flemish Ardennes is estimated to be $15.80 \pm$ $3.50 \mathrm{~km}^{2}$. This corresponds to 2.9 to $4.5 \%$ of the $430 \mathrm{~km}^{2}$ study area, and is two to three times larger than the mapped affected area of $6.57 \mathrm{~km}^{2}$. The latter is of the same order as estimates made by Malamud et al. [19] for other incomplete inventories throughout the world.

Compared to total areas affected by LS in mountainous areas, the estimated percentages of 2.9 to $4.5 \%$ in the Flemish Ardennes are still rather low. Furthermore, they are maximum estimates, because for the frequency-size statistics all individual LS located within a cluster should be included in the analysis. It is not sufficient to include the external boundaries of the cluster [19]. For the LS inventory of the Flemish Ardennes, however, the delineation of individual LS inside a LS cluster was only possible for reactivations that occurred during the last 20 to $30 \mathrm{yr}$, and that were not obliterated by human activities or vegetation. Older reactivations within deepseated LS could not be mapped separately, and therefore an important fraction of the estimated number of LS will be located within one of the mapped large, deep-seated LS, and the true total affected area will be smaller than the estimated values of $15.80 \pm 3.50 \mathrm{~km}^{2}$. Hence, in contrast with what the estimate suggests, the total affected area derived from our field survey-and LIDAR-based LS inventory (i.e. $6.57 \mathrm{~km}^{-2}$ ) is representing more than one third of the true affected area.

\section{Discussion and conclusions}

This study focused on the frequency distribution of $A_{\mathrm{L}}$ in a hilly region in Belgium. Different to event and historical LS inventories compiled in mountain areas, the frequency density of LS in the Flemish Ardennes probably consists of the superposition of two populations, i.e. (1) recent, small shallow LS and (2) old, moderate to large, deep-seated LS. When investigating the small and large LS together (Fig. 4A), each LS population is described by a different negative power-law relation with exponents $-\beta$ of -0.58 and -2.31 respectively. Only Brardinoni and Church ([18]; Table 1) obtained a more or less comparable distribution when investigating LS volumes of a historical inventory derived from the interpretation of aerial photographs in a densely forested region in Canada. In their study, the number of small LS not visible on aerial photographs was estimated from a comparison between limited field mapping and aerial photo interpretation in a small subcatchment, and it was 
only the addition of a large proportion of estimated 'not visible' LS that transformed the frequency distribution of LS volumes, characterized by a positive and a negative power-law relation, to a distribution, characterized by two negative power-law relations. Furthermore no explanation was given for the slope break between the two negative power-law relations.

At present small $\left(A_{\mathrm{L}}<1-2 \cdot 10^{-2} \mathrm{~km}^{2}\right)$ new LS initiations or reactivations within existing LS are common in the Flemish Ardennes as, on average, they are recorded two to three times a year [4]. The initiation of deep-seated LS, on the other hand, was not recorded over the last $100 \mathrm{yr}$, and also the reactivation of entire deep-seated LS (i.e. depletion and accumulation area) was only reported three times. The fact that recent LS events are restricted in spatial extent (Fig. 4C) and that no deep-seated LS was initiated during at least the last $100 \mathrm{yr}$ suggest that recent and old LS were initiated by causal factors with significantly different magnitudes. This hypothesis corresponds to the findings of Van Den Eeckhaut [5] stating that, compared to old large LS mainly triggered by natural factors, recent small LS are mainly caused by local human activities. The triggering of small LS by local anthropogenic factors such as the removal of lateral support at the LS foot or overloading of the LS depletion area for construction works, poor and insufficient sewerage systems, and the obstruction of springs also explains the negative power-law relation obtained for LS with $A_{\mathrm{L}}<10^{-2} \mathrm{~km}^{2}$. The decrease in shear strength due to such local human activities is generally restricted to a limited part of the slope section. Hence, smaller LS are more likely to occur, and the number of LS initiated or reactivated by an anthropogenic factor decreases with $A_{\mathrm{L}}$, following a power-law relation. It is not possible to obtain such a negative power-law from the distribution proposed by Malamud et al. [19] and others, because a decrease in detectable smaller LS with time, would still result in a frequency distribution of $A_{\mathrm{L}}$ that, although shifted to the lower right of the graph, is characterized by a positive and negative power-law separated by a rollover (e.g. Fig. 3B).

Such a distribution was found for the old LS in the study area (Fig. 4B). Hence, in contrast with the distribution of recent LS (Fig. 4C) the distribution of old LS follows the frequency density of $A_{\mathrm{L}}$ as suggested by Malamud et al. [19]. Therefore it is relevant to apply the procedure proposed by Malamud et al. [19] to old LS in the Flemish Ardennes in order to estimate the true total number of landslides. The results suggest that over time more than 5000 LS have affected 2.9 to $4.5 \%$ of the study area. In Section 3.1, it was already mentioned that $4.5 \%$ can be seen as a maximum area affected by LS as small LS within LS clusters are taken into account separately. The total number of $5000 \mathrm{LS}$, both inside and outside existing LS clusters might seem large at first sight, but is not unrealistic since AMS radiocarbon dating of 2 samples of organic matter found in a pond located in reverse slopes of a deep-seated rotational earth slide [38] revealed ages of Cal BC 6710-6490 (KIA-28305) and Cal BC 320-420 (KIA-29790), suggesting that LS initiations and reactivations can have occurred over several millennia.

The results of our study contribute to the understanding of frequency distributions of $A_{\mathrm{L}}$ in different environments, and are represented in a conceptual model summarizing the present-day knowledge on LS distributions (Fig. 5). The first milestone was the sand pile model of Bak et al. [26], where the initiation of avalanches was controlled by friction, and where the frequency distribution of avalanche sizes followed a negative power-law distribution (Fig. 5A). Then, there were studies such as those compiled in Table 1. All these studies dealt with mountain areas where the surface morphology and lithology are the result of tectonic uplift and erosion and weathering processes, and where generally a large fraction of the area is in a marginally stable state. The occurrence of either a natural triggering factor such as rainfall (e.g. [14]), earthquake shaking (e.g. [8]) or rapid snowmelt (e.g. [13]) or an anthropogenic intervention with regional impact such as widespread deforestation [18] generally initiated LS of different sizes throughout the region. Of course, the LS magnitude ( $m_{\mathrm{L}}$; Eq. (2)) increases with the magnitude of the triggering event. Under these conditions, LS frequency distributions are characterized by a positive power-law scaling for small LS, controlled by cohesion, and a negative power-law scaling for moderate and large LS, controlled by friction, separated from each other by a rollover (Fig. 5B). Malamud et al. [19] even found indications that all LS inventories, either complete inventories caused by a single triggering event or incomplete historical inventories caused by several events, could be represented by one universal relation (i.e. Eq. (1)) with an exponent $-\beta$ of -2.4 for the negative power-law tale. The studies compiled in Table 1, however, reveal that the range of $\beta$ values of individual inventories (i.e. between 1.4 and 3.5) is considerable.

As the distribution obtained for the LS in the Flemish Ardennes cannot be explained with the 'universal distribution' described by Malamud et al. [19], we propose an additional distribution for historical LS inventories compiled in populated hilly areas that are located relatively far from plate boundaries in continental zones where tectonic activity is limited. It is possible that in the past and under different environmental conditions, natural factors have triggered LS throughout such regions. 

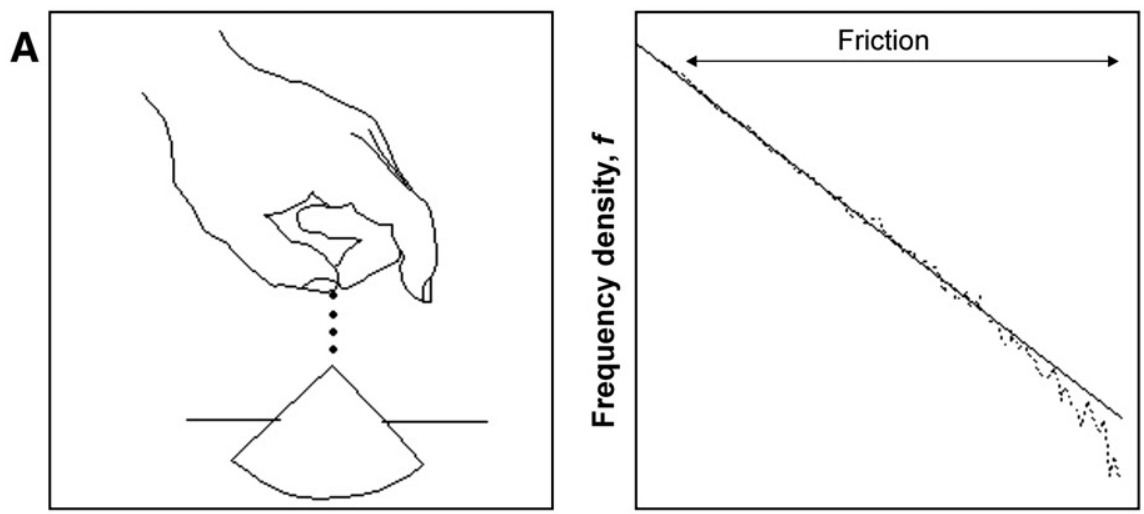

Number of grains, $s$
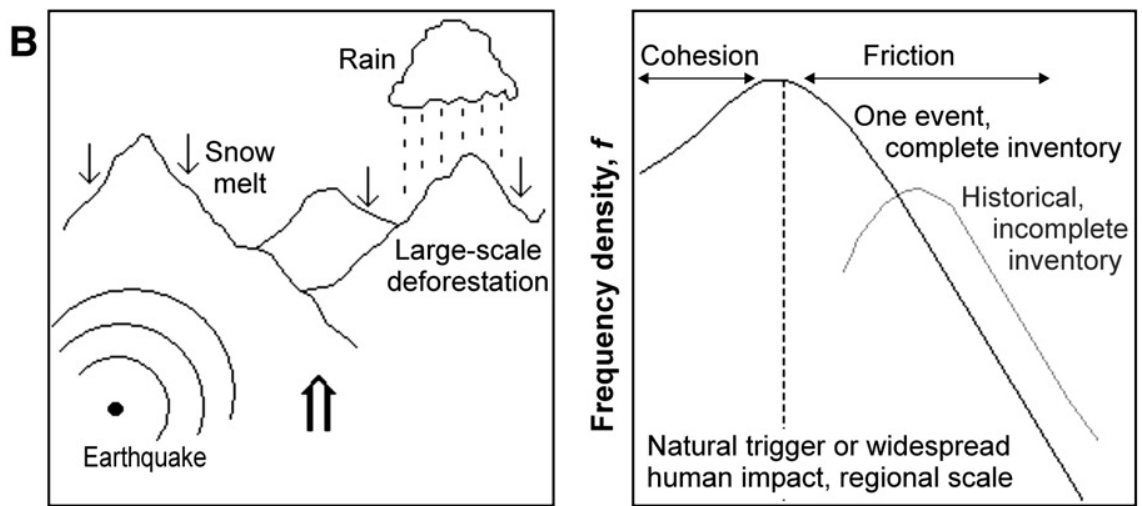

$\downarrow$ Weathering

$\Uparrow$ Tectonic uplift

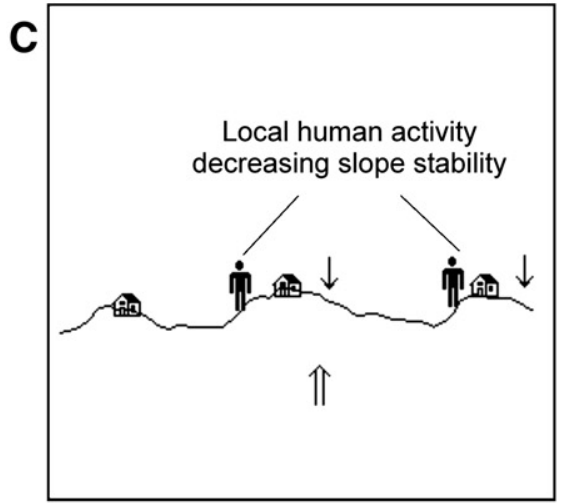

$\downarrow$ Limited weathering

$\Uparrow$ Limited tectonic uplift

Landslide area, $A_{L}$

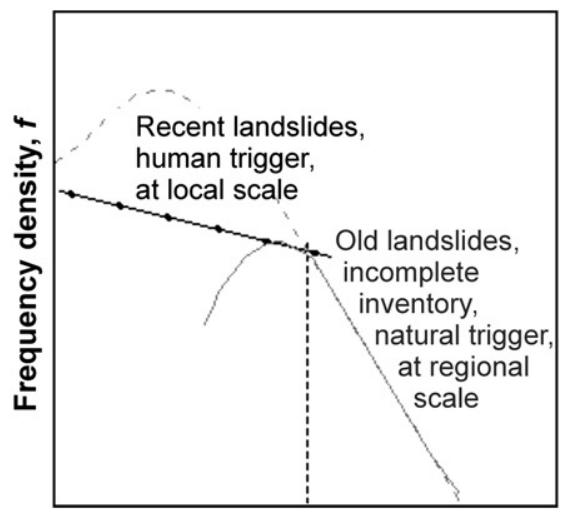

Landslide area, $A_{L}$

Fig. 5. Conceptual models of frequency-area distributions of landslides: (A) Sand pile model of Bak et al. [26], and corresponding negative powerlaw relation (i.e. $f(S) \approx S^{-\beta}$ ) between the number of avalanches involving $S$ grains, $f(S)$, and the number of grains, $S$; (B) Mountain areas where landslides are mainly triggered by natural factors or large-scale human interventions, and corresponding positive power-law relation for small landslides, negative power-law relation with an average exponent of 2.4 for moderate and large landslides, and rollover in the transition zone [19]; (C) Populated hilly regions where local human interventions are triggering landslides (as observed in this study), and corresponding negative powerlaw relation with an exponent significantly smaller than 2.4 for recent, small landslides. For old landslides the distribution is similar to the one shown in (B) for historical and incomplete inventories. 
Incomplete historical inventories of LS triggered under these conditions have frequency-area distributions (Fig. 5C) similar to other historical LS inventories that are caused by natural triggering factors (Fig. 5B). Under the present-day rainfall conditions, however, hillslope sections in hilly regions with limited tectonic activity are generally relatively stable. LS are only initiated or reactivated on hillslope sections locally affected by human activities that decrease the slope stability by either changing the hydrological or the topographical characteristics of the hillslope section. These local human interventions have a local response resulting in LS with a limited size, and the number of LS will decrease with $A_{\mathrm{L}}$ following a power-law relation with an exponent $-\beta$ significantly smaller than -2.4 . It is this present-day higher temporal frequency of small LS that obscures the positive power-law relation and rollover, obtained for the old LS, when analysing old and recent LS together. For the Flemish Ardennes this conceptual model allows to explain the observed frequency-area distribution, but analysis of other, similar LS inventories is required to strengthen the results obtained.

\section{Acknowledgements}

This research is supported by the Fund for Scientific Research - Flanders. The authors thank the anonymous referee and Prof. G. D. Price for their critical remarks that helped in improving the manuscript.

\section{References}

[1] L. Ost, M. Van Den Eeckhaut, J. Poesen, M.C. VanmaerckeGottigny, Characteristics and spatial distribution of large landslides in the Flemish Ardennes (Belgium), Z. Geomorphol. 47 (2003) 329-350.

[2] M. Van Den Eeckhaut, J. Poesen, G. Verstraeten, V. Vanacker, J. Moeyersons, J. Nyssen, L.P.H. Van Beek, The effectiveness of hillshade maps and expert knowledge in mapping old deepseated landslides, Geomorphology 67 (2005) 351-363.

[3] M. Van Den Eeckhaut, J. Poesen, G. Verstraeten, V. Van Acker, J. Nyssen, J. Moeyersons, L.P.H. Van Beek, L. Vandekerckhove, The use of LIDAR-derived images for mapping old landslides under forest. Earth Surf. Processes Landf (in press).

[4] M. Van Den Eeckhaut, T. Vanwalleghem, J. Poesen, G. Govers, G. Verstraeten, Prediction of landslide susceptibility using rare events logistic regression: a case-study in the Flemish Ardennes (Belgium), Geomorphology 76 (2006) 392-410.

[5] M. Van Den Eeckhaut, 2006. Spatial and temporal patterns of landslides in hilly regions - the Flemish Ardennes (Belgium). $\mathrm{PhD}$ Thesis, Faculty of Sciences, Department of GeographyGeology, K. U. Leuven, Belgium, ISBN 90-8649-010-7, pp. 250.

[6] M. Van Den Eeckhaut, J. Poesen, O. Dewitte, A. Demoulin, H. De Bo, M.C. Vanmaercke-Gottigny, Reactivation of old landslides: lessons learned from a case-study in the Flemish Ardennes (Belgium), Soil Use and Management (in press).
[7] N. Hovius, C.P. Stark, P.A. Allen, Sediment flux from a mountain belt derived by landslide mapping, Geology 25 (1997) 231-234.

[8] J.D. Pelletier, B.D. Malamud, T. Blodgett, D.L. Turcotte, Scaleinvariance of soil moisture variability and its implications for the frequency-size distributions of landslides, Eng. Geol. 48 (1997) 255-268.

[9] B.D. Malamud, D.L. Turcotte, Self-organized criticality applied to natural hazards, Nat. Hazards 20 (1999) 93-116.

[10] N. Hovius, C.P. Stark, C. Hao-Tsu, L. Jiun-Chuan, Supply and removal of sediment in a landslide-dominated mountain belt Central Range, Taiwan, J. Geol. 108 (2000) 73-89.

[11] C.P. Stark, N. Hovius, The characterisation of landslide size distributions, Geophys. Res. Lett. 28 (2001) 1091-1094.

[12] Y. Martin, K. Rood, J.W. Schwab, M. Church, Sediment transfer by shallow landslides in the Queen Charlotte Islands, British Columbia, Can. J. Earth Sci. 39 (2002) 189-205.

[13] F. Guzzetti, B.D. Malamud, D.L. Turcotte, P. Reichenbach, Power-law correlations of landslide areas in central Italy, Earth Planet. Sci. Lett. 195 (2002) 169-183.

[14] G.B. Crosta, P.D. Negro, P. Frattini, Soil slips and debris flows on terraced slopes, Nat. Hazards Earth Syst. Sci. 3 (2003) 31-42.

[15] J. Iwahashi, S. Watanabe, T. Furuya, Mean slope-angle frequency distribution and size frequency distribution of landslide masses in Higashikubiki area, Japan, Geomorphology 50 (4) (2003) 349-364

[16] R.H. Guthrie, S.G. Evans, Analysis of landslide frequencies and characteristics in a natural system, coastal British Columbia, Earth Surf. Processes Landf. 29 (2004) 1321-1339.

[17] R.H. Guthrie, S.G. Evans, Magnitude and frequency of landslides triggered by a storm event, Loughborough, British Columbia, Nat. Hazards Earth Syst. Sci. 4 (2004) 475-483.

[18] F. Brardinoni, M. Church, Representing the landslide magnitude-frequency relation: Capilano River Basin, British Columbia, Earth Surf. Processes Landf. 29 (2004) 115-124.

[19] B.D. Malamud, D.L. Turcotte, F. Guzzetti, P. Reichenbach, Landslide inventories and their statistical properties, Earth Surf. Processes Landf. 29 (2004) 687-711.

[20] B.D. Malamud, D.L. Turcotte, F. Guzzetti, P. Reichenbach, Landslides, earthquakes, and erosion, Earth Planet. Sci. Lett. 229 (2004) 45-59.

[21] O. Korup, Distribution of landslides in southwest New Zealand, Landslides 2 (2005) 43-51.

[22] F. Catani, N. Casagli, L. Ermini, G. Righini, G. Menduni, Landslide hazard and risk mapping at catchment scale 2005 Arno River basin, Landslides 2 (4) (2005) 329-342.

[23] O. Katz, E. Aharonov, Landslides in vibrating sand box: what controls types of slope failure and frequency magnitude relations? Earth Planet. Sci. Lett. 247 (2006) 280-294.

[24] H.B. Havenith, I. Torgoev, A. Meleshko, Y. Alioshin, A. Torgoev, G. Danneels, Landslides in the Mailuu-Suu Valley, Kyrgyzstan hazards and impacts, Landslides 3 (2) (2006) 137-147.

[25] C. Chien-Yuan, Y. Fan-Chieh, L. Sheng-Chi, C. Kei-Wai, Discussion of Landslide Self-Organized Criticality and the Initiation of Debris Flow, Earth Surf. Processes Landf 32 (2007) 197-209.

[26] P. Bak, C. Tang, K. Wiesenfield, Self-organized critically, Phys. Rev., A 38 (1988) 364-374.

[27] P. Bak, K. Chen, The physics of fractals, Physica, D 38 (1989) 5-12.

[28] P. Bak, Self-organized critically, Physica, A 163 (1990) 403-409.

[29] S. Hergarten, Landslides, sandpiles, and self-organized criticality, Nat. Hazards Earth Syst. Sci. 3 (2003) 505-514.

[30] G. Yakovlev, W.I. Newman, D.L. Turcotte, A. Gabrielov, An inverse cascade model for self-organized complexity and natural hazards, Geophys. J. Int. 163 (2005) 433-442. 
[31] W. De Vos, J. Verniers, A. Herbosch, M. Vanguestaine, A new geological map of the Brabant Massif, Belgium, Geol. Mag. 130 (1993) 606-611.

[32] P. Jacobs, M. De Ceukelaire, W. De Breuck, G. De Moor, 1999, Text describing the Belgian Geological Map, Flemish Region, Map Sheet 29 Kortrijk, Map Scale 1/50000 (in Dutch), Ministerie van Economische zaken en Ministerie van de Vlaamse Gemeenschap, Brussels, 68 pp.

[33] P. Jacobs, V. Van Lancker, M. De Ceukelaire, W. De Breuck, G. De Moor, 1999, Text describing the Belgian Geological Map, Flemish Region, Map Sheet 30 Geraardsbergen, Map Scale 1/50000 (in Dutch), Ministerie van Economische zaken en Ministerie van de Vlaamse Gemeenschap, Brussels, 58 pp.

[34] I.W.O.N.L., 1987, Text clarifying the Belgian Soil Map, Map Sheet 98E Ronse (in Dutch), Uitgegeven onder de auspiciën van het Instituut tot aanmoediging van het Wetenschappelijk Onderzoek in Nijverheid en Landbouw, Brussels.

[35] NGI (National Geographical Institute), 1972, Topographical map of Belgium (1:10000), Sheets 29/3-4-7-8 and 30/1-2-5-6, National Geographical Institute, Brussels.

[36] P. Sigrist, P. Coppin, M. Hermy, Impact of forest canopy on quality and accuracy of GPS measurements, J. Remote Sens. 20 (1999) 3595-3610.
[37] DEM of Flanders, MVG-LIN-AWZ and MVG-LIN-AMINAL (GIS-Vlaanderen), http://www.gisvlaanderen.be/gis/diensten/ geo-vlaanderen/?artid=240,2005.

[38] M. Van Den Eeckhaut, J. Poesen, G. Verstraeten, Morphology, internal structure and age of a dormant landslide under forest, the Collinabos landslide (Belgium), Geomorphology (in press).

[39] D.K. Keefer, Landslides caused by earthquakes, Geol. Soc. Am. Bull. 95 (1984) 406-421.

[40] F. Halet, Glissements de terrain aux environs de Renaix, Bull. Soc. Belge Géol. 18 (1904) 161-163.

[41] M.A. Lefèvre, 1926-1927, Glissements de terrain dans les collines de Renaix, Ann. Soc. Geol. Belg. 50, 29-35.

[42] OC-GIS Vlaanderen, 1998, Mid scale orthophoto images of map sheet 30-5, scale: 1:12,000, Ondersteunend Centrum GIS Vlaanderen, Belgium, Gent.

[43] S.G. Evans, D.M. Cruden, P.T. Bobrowsky, R.H. Guthrie, T.R. Keegan, D.G.E. Liverman, D. Perret, Landslide risk assessment in Canada; a review of recent developments, in: O. Hungr, R. Fell, R. Couture, E. Eberhardt (Eds.), Landslide Risk Management: Proceedings of the International Conference on Landslide Risk Management, A.A. Balkema, Vancouver, Leiden, 2005, pp. 352-366. 